Check for updates

Cite this: RSC Adv., 2018, 8, 29967

Received 25th July 2018

Accepted 20th August 2018

DOI: $10.1039 / \mathrm{c} 8 \mathrm{ra06297h}$

rsc.li/rsc-advances

\section{Identification of 4-isopropyl-thiotropolone as a novel anti-microbial: regioselective synthesis, NMR characterization, and biological evaluation $\uparrow$}

\author{
Mohamed Elagawany, ${ }^{\mathrm{ab}}$ Lamees Hegazy, ${ }^{\mathrm{a}}$ Feng Cao, ${ }^{\mathrm{c}}$ Maureen J. Donlin, ${ }^{\mathrm{d}}$ \\ Nigam Rath, ${ }^{e}$ John Tavis ${ }^{f}$ and Bahaa Elgendy (ID *ag
}

\begin{abstract}
We have synthesized and separated tosylated thujaplicin isomers for the first time, and elucidated their structures using 1D, 2D-NMR techniques and X-ray crystallography. The tosylated isomers were used to synthesize 4-isopropyl-thiotropolone and 6-isopropyl-thiotropolone in a regioselective manner. ${ }^{1} \mathrm{H}$ and

${ }^{13} \mathrm{C}$ Chemical shifts of synthesized isomers were fully assigned using several NMR experiments, and their isotropic magnetic shielding was calculated using the GIAO (Gauge Including Atomic Orbitals) method and the B3LYP def2-TZVPP level of theory. The calculated chemical shift values were in a good agreement with the experimental results. The biological activity of all synthesized compounds was evaluated against the fungal pathogen Cryptococcus neoformans and four different bacterial strains (Staphylococcus aureus (ATCC 29213), E. coli (ATCC 35218), Acinetobacter baumannii and Pseudomonas aeruginosa (ATCC 27853)). 4-Isopropyl-thiotropolone was found to inhibit Staphylococcus aureus in a low micro molar range and exhibit good therapeutic index and ADME properties. This compound can be used for future lead optimization to design inhibitors against Staphylococcus aureus (ATCC 29213).
\end{abstract}

\section{Introduction}

The troponoid core is well known in hundreds of natural products. The tropone ring has a unique structure and properties and despite their non-benzenoid nature, they are planar and possess aromatic character. Natural and synthetic compounds that have the troponoid core have profound biological activities and have been used as antitumor, ${ }^{1-3}$ antifungal, ${ }^{4}$ and antimicrobial agents. ${ }^{5}$ The biological activities of these compounds has been mainly attributed to their inhibitory effect on bimetallic enzymes. ${ }^{6,7}$ Colchicine (1) is the most recognized member of this family because it has been used for the treatment of gout ${ }^{8}$ and

${ }^{a}$ Departments of Pharmacology and Physiology, Saint Louis University School of Medicine, St. Louis, MO, USA

${ }^{b}$ Department of Pharmaceutical Chemistry, Faculty of Pharmacy, Damanhour University, Damanhour, Egypt

'John Cochran Division, Department of Veteran's Affairs Medical Center, 915 North Grand Blvd., St. Louis, MO 63106, USA

${ }^{d}$ Edward A. Doisy Department of Biochemistry and Molecular Biology, Saint Louis University School of Medicine, St. Louis, Missouri, USA

${ }^{e}$ Department of Chemistry and Biochemistry, Center for Nanoscience, University of Missouri - St. Louis, One University Boulevard, St. Louis, USA

${ }^{f}$ Department of Molecular Microbiology and Immunology, The Saint Louis University Liver Center, Saint Louis University School of Medicine, St. Louis, Missouri, USA

${ }^{g}$ Chemistry Department, Faculty of Science, Benha University, Benha 13518, Egypt. E-mail: belgendy@fsc.bu.edu.eg

$\dagger$ Electronic supplementary information (ESI) available. CCDC 1856450. For ESI and crystallographic data in CIF or other electronic format see DOI: $10.1039 / \mathrm{c} 8 \mathrm{ra06297h}$ familial Mediterranean fever ${ }^{9}$ since the time of ancient Egyptians. ${ }^{10}$ Hinokitiol ( $\beta$-thujaplicin) (2) is among the known tropolone derivatives that showed inhibitory effects against Chlamydia trachomatis and has clinical potential to be used as a topical drug to prevent sexually transmitted diseases. ${ }^{11}$

Thiotropolones have not been widely explored compared to structurally related hydroxytropolones. Some examples exist in literature that shows anticancer activity such as thiocolchicin (3), which can act as tubulin ${ }^{12}$ or topoisomerase II inhibitor. ${ }^{13}$ Thiotropocin (4) is another structurally related antibiotic that was isolated from Pseudomonas sp. CB-104 in 1984. ${ }^{14,15}$ This antibiotic was found to exhibit antibacterial, antifungal, and antiprotozoal activities in vitro. Recently, Donlin and coworkers ${ }^{4}$ reported that thiotropolone 5 can inhibit the growth of the fungus Cryptococcus neoformans with a minimal $80 \%$ inhibitory concentration $\left(\mathrm{MIC}_{80}\right)$ of $0.25 \mu \mathrm{M}$. In our effort to design and synthesize new thiotropolones to treat pathogenic fungi and multidrug resistant bacteria, we used the natural product $\beta$-thujaplicin (2) as starting point (Fig. 1).

Here, we report for the first time the isolation of the intractable mixture of tosylated thujaplicines, $\mathbf{8}$ and $\mathbf{9}$, their full NMR assignments and the X-ray structure of $\mathbf{8}$. Moreover, we report the synthesis, full NMR chemical shift assignments of 4-isopropyl and 6-isopropyl-2-mercaptocyclohepta-2,4,6trien-1-one, 10 and 11, and their anti-Cryptococcus neoformans and antibacterial activity. Moreover, we have evaluated the ADME (adsorption, distribution, metabolism, excretion and toxicity) properties of tested compounds. 


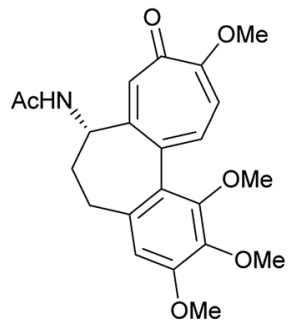

1

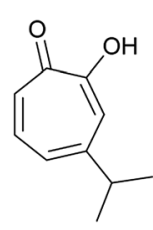

2

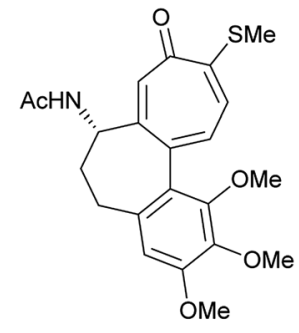

3<smiles>O=c1cccc(O)c2c(=O)ooc12</smiles>

4

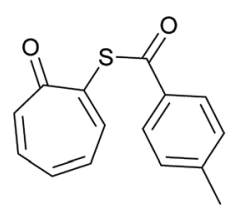

5
Fig. 1 Examples of biologically active tropolones.

\section{Results and discussion}

Tosylation is usually the first step toward functionalization of hydroxytropolones to prepare biologically active derivatives. Under standard conditions of tosylation, where base is used in excess, the formed anion of unsymmetrical hydroxytropolones (Fig. 2A) undergoes isomerization to give a mixture of isomers. During their attempt to synthesize $O$-alkyl derivatives of 4-isopropyl-tropolone as ribonucleotide reductase inhibitors, Crozet and his co-workers ${ }^{16}$ observed the formation of a mixture of 4and 6-isopropyl derivatives (1:1 mixture). They were only able to obtain sufficient amounts of the 4-isopropyl derivatives in a pure form suitable for testing. Similarly, tosylation of colchicine (1) gave the biologically inactive 9-tosyloxycolchicide isomer $(6)$ as the major product $(\approx 74 \%)$ while the biologically active 10-tosyloxycolchicide isomer (7) was the minor product $(\approx 26 \%) \cdot{ }^{17}$

Tosylated thujaplicines, $\mathbf{8}$ and $\mathbf{9}$, are important synthetic intermediates in the synthesis of many biologically active tropolones. For example, they were used as an intermediate in the preparation of copper aminotropones, which were found to be more effective than a commercial toothpaste formulation in inhibiting plaque formation. ${ }^{18}$ The inability to separate 8 and 9 and their use as a mixture of isomers complicates the purification of the desired ligands. Obtaining such mixture of isomers is undesirable, and selective tosylation or facile separation of isomers is crucial from the synthetic point of view. ${ }^{18}$

Hinokitiol ( $\beta$-thujaplicin) (2) was treated with $p$-toluenesulfonyl chloride in presence of pyridine in dichloromethane (DCM) at room temperature to give a mixture of 5-isopropyl-7-oxocyclohepta1,3,5-trien-1-yl-4-methylbenzenesulfonate (8) and 3-isopropyl-7oxocyclohepta-1,3,5-trien-1-yl-4-methylbenzenesulfonate (9) in $\approx 1: 1$ ratio. The isolation of this mixture was reported to be intractable. ${ }^{19}$ To obtain 9 (the isomer of the natural product) exclusively, it has to be through multistep synthesis. The first step involves iodination of 2 in position 7 followed by tosylation of hydroxyl group at position 2 . The final step is to remove the iodine
A.

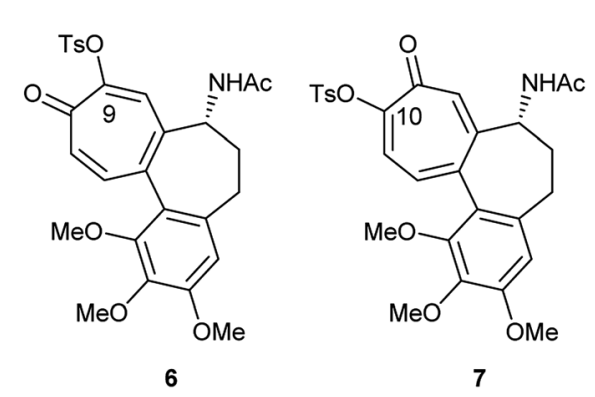

Fig. 2 (A) $\beta$-Thujaplicin anions. (B) Tosyloxycolchicides 6 and 7.

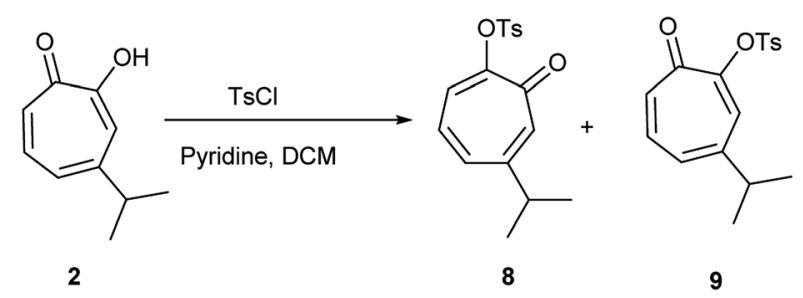

Scheme 1 Synthesis of compounds 8 and 9

by hydrogenation using $\mathrm{Pd} / \mathrm{C}(10 \%)$ in presence of anhydrous sodium acetate. ${ }^{19}$ Nevertheless, we were able to separate the two isomers using a Reveleris X2 flash chromatography system. The structures of 8 and 9 (Scheme 1) were elucidated using 1D and 2D NMR spectroscopy and single crystal X-ray diffraction.

Compound 8 was obtained as colorless sharp needles. Its molecular formula $\mathrm{C}_{17} \mathrm{H}_{18} \mathrm{O}_{4} \mathrm{~S}$ was determined by HRESIMS data $\left(\mathrm{m} / z 341.0816[\mathrm{M}+\mathrm{Na}]^{+}\right.$, calc. 341.0818). The analysis of ${ }^{1} \mathrm{H}$, ${ }^{13} \mathrm{C}$, COSY, HSQC, and HMBC spectra revealed the presence of a singlet proton $\mathrm{H}-7\left(\delta_{\mathrm{C}} / \delta_{\mathrm{H}} 137.7 / 7.05, \mathrm{C}-7\right)$. This proton shows two bond correlations with C-1 $\left(\delta_{\mathrm{C}} 179.1\right)$ and C-6 $\left(\delta_{\mathrm{C}} 157.3\right)$ and strong three bond correlations with C-2 $\left(\delta_{\mathrm{C}} 154.5\right)$ and C-8 $\left(\delta_{\mathrm{C}}\right.$ 38.3). Furthermore, the one methine septet $\mathrm{H}-8\left(\delta_{\mathrm{C}} / \delta_{\mathrm{H}} 38.3 / 2.73\right.$, $\mathrm{C}-8)$ shows two bond correlations to C- 6 and three bond correlations to C-7. The two-methyl doublet $\mathrm{H}_{3}-9$ and $\mathrm{H}_{3}-10\left(\delta_{\mathrm{C}} / \delta_{\mathrm{H}}\right.$ 22.6/1.17, C-9 and C-10) shows a strong three bond correlation to C-6. $\mathrm{H}-4\left(\delta_{\mathrm{C}} / \delta_{\mathrm{H}} 129.1 / 6.88, \mathrm{C}-4\right)$ shows strong three bond correlations to C-2 and C-6, which further confirms the location of tosyl and isopropyl groups (Table 1).

We have calculated both ${ }^{1} \mathrm{H}$ and ${ }^{13} \mathrm{C}$ isotropic chemical shielding of 8 at the B3LYP/def2-TZVPP level of theory. Correlation plots between experimental and calculated chemical shifts shows very good correlations with correlation coefficients $\left(R^{2}\right)$ of 0.9946 and 0.9755 for ${ }^{13} \mathrm{C}$ and ${ }^{1} \mathrm{H}$ NMR chemical shifts, respectively (Fig. S50†).

Compound 9 was obtained as a white powder. Its molecular formula $\mathrm{C}_{17} \mathrm{H}_{18} \mathrm{O}_{4} \mathrm{~S}$ was determined by HRESIMS data $(\mathrm{m} / \mathrm{z}$ 
Table 1 Experimental and calculated ${ }^{1} \mathrm{H}$ and ${ }^{13} \mathrm{C}$ isotropic chemical shifts (ppm) of compounds 8 and $9^{a}$
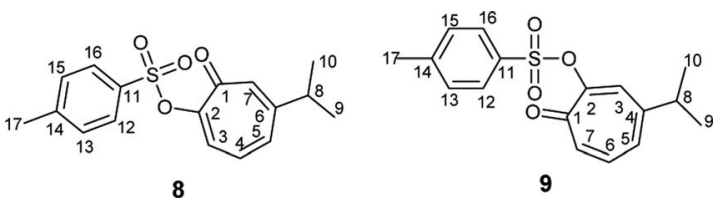

\begin{tabular}{|c|c|c|c|c|}
\hline Atom & $\delta_{\text {Exp }} 8$ & $\delta_{\text {Calc }} \mathbf{8}$ & $\delta_{\text {Exp }} 9$ & $\delta_{\text {Calc }} 9$ \\
\hline $\mathrm{C}-1$ & 179.1 & 188.9 & 178.9 & 189.1 \\
\hline $\mathrm{C}-2$ & 154.5 & 173.1 & 154.6 & 171.4 \\
\hline $\mathrm{C}-3$ & 129.2 & 140.9 & 131.7 & 145.6 \\
\hline $\mathrm{C}-4$ & 129.6 & 142.1 & 152.4 & 167.8 \\
\hline $\mathrm{C}-5$ & 136.6 & 143.4 & 130.5 & 138.2 \\
\hline C-6 & 157.3 & 167.1 & 137.0 & 144.5 \\
\hline $\mathrm{C}-7$ & 137.7 & 155.5 & 138.9 & 152.4 \\
\hline $\mathrm{C}-8$ & 38.3 & 51.2 & 38.0 & 48.1 \\
\hline C-9 and C-10 & 22.6 & 28.9 & 22.7 & 28.3 \\
\hline C-11 & 133.4 & 151.9 & 133.4 & 151.7 \\
\hline C-12 and C-16 & 128.4 & 141.4 & 128.5 & 141.4 \\
\hline C-13 and C-15 & 129.2 & 138.5 & 129.6 & 138.7 \\
\hline C-14 & 145.3 & 157.3 & 145.6 & 157.2 \\
\hline C-17 & 21.7 & 27.3 & 21.8 & 27.4 \\
\hline $\mathrm{H}-3$ & 7.29 & 8.12 & 7.36 & 8.31 \\
\hline $\mathrm{H}-4$ & 6.88 & 7.69 & - & - \\
\hline $\mathrm{H}-5$ & 6.98 & 7.73 & 6.93 & 7.68 \\
\hline H-6 & - & - & 7.14 & 7.94 \\
\hline $\mathrm{H}-7$ & 7.05 & 8.23 & 7.02 & 8.044 \\
\hline $\mathrm{H}-8$ & 2.73 & 3.47 & 2.80 & 3.64 \\
\hline $\mathrm{H}-9$ and $\mathrm{H}-10$ & 1.17 & 2.01 & 1.21 & 2.05 \\
\hline $\mathrm{H}-12$ and $\mathrm{H}-16$ & 7.89 & 10.15 & 7.90 & 10.07 \\
\hline $\mathrm{H}-13$ and $\mathrm{H}-15$ & 7.31 & 8.27 & 7.33 & 8.28 \\
\hline $\mathrm{H}-17$ & 2.42 & 3.35 & 2.43 & 3.3445 \\
\hline
\end{tabular}

${ }^{a}{ }^{13} \mathrm{C}$ assignments were based on HSQC and HMBC spectra. ${ }^{1} \mathrm{H}$ assignments were based on $1 \mathrm{D}^{-}{ }^{1} \mathrm{H}$ NMR and COSY spectra.

341.0818 $[\mathrm{M}+\mathrm{Na}]^{+}$, calc. 341.0815$)$. The analysis of ${ }^{1} \mathrm{H},{ }^{13} \mathrm{C}$, COSY, HSQC, and HMBC spectra revealed the presence of a singlet proton $\left(\delta_{\mathrm{C}} / \delta_{\mathrm{H}} 131.7 / 7.36, \mathrm{C}-3\right)$. This proton shows two bond correlations with $\mathrm{C}-2\left(\delta_{\mathrm{C}} 154.5\right)$ and $\mathrm{C}-4\left(\delta_{\mathrm{C}} 152.4\right)$ and strong three bond correlations with C-1 $\left(\delta_{\mathrm{C}} 178.9\right)$ and C-8 $\left(\delta_{\mathrm{C}}\right.$ 38.0). Furthermore, the one methine septet $\mathrm{H}-8\left(\delta_{\mathrm{C}} / \delta_{\mathrm{H}} 38.0 / 2.80\right.$, C-8) shows two bond correlations to C-4 $\left(\delta_{\mathrm{C}} 152.4\right)$ and three bond correlations to C-3. The two-methyl doublet $\mathrm{H}_{3}-9$ and $\mathrm{H}_{3}$ $10\left(\delta_{\mathrm{C}} / \delta_{\mathrm{H}} 22.7 / 1.21, \mathrm{C}-9\right.$ and $\left.\mathrm{C}-10\right)$ shows a strong three bond correlation to C-6. H-6 $\left(\delta_{\mathrm{C}} / \delta_{\mathrm{H}} 137.0 / 7.14, \mathrm{C}-6\right)$ shows strong three bond correlations to $\mathrm{C}-1$ and $\mathrm{C}-4$, which further confirms the location of carbonyl and isopropyl groups. Besides, H-7 $\left(\delta_{\mathrm{C}} / \delta_{\mathrm{H}}\right.$ $138.9 / 7.02, \mathrm{C}-7)$ shows a strong three bond correlation to C-2, which confirms the position of tosyl group (Table 1).

We have calculated both ${ }^{1} \mathrm{H}$ and ${ }^{13} \mathrm{C}$ isotropic chemical shielding of $\mathbf{9}$ at the B3LYP/def2-TZVPP level of theory. Correlation plots between experimental and calculated chemical shifts shows very good correlations with $R^{2}$ of 0.9962 and 0.9789 for ${ }^{13} \mathrm{C}$ and ${ }^{1} \mathrm{H}$ NMR chemical shifts, respectively (Fig. S51†).

Our NMR assignments were further confirmed by obtaining an X-ray crystal structure of compound 8 (Fig. 3). The X-ray shows that the tosyl group is in position 2 while isopropyl

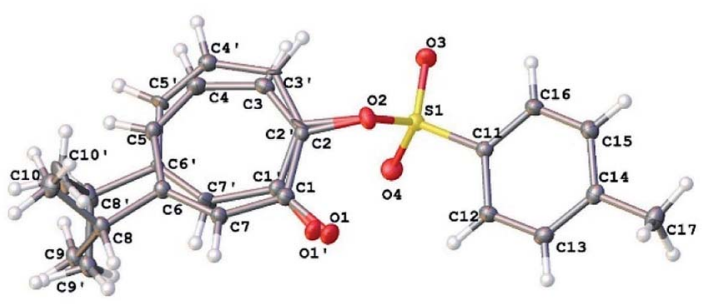

Fig. 3 X-ray crystal structure of compound 8 showing the atomnumbering scheme.

group is in position 6 of the tropolone ring. Compound 8 was crystallized from ethyl acetate $(0.2 \mathrm{~mL})$, ether $(0.5 \mathrm{~mL})$, and hexanes $(10 \mathrm{~mL})$ by solvent evaporation. Crystallographic data is given in Table S1. $\uparrow$ The crystals of compound $\mathbf{8}$ crystallize in the monoclinic space group $P 2_{1} / c$ with four molecules in the unit cell $(Z=4)$ of dimensions $a=5.62, b=28.31, c=9.51 \AA$ and $\beta=$ 92.4 $. V=1512.31(11) \AA^{3}$.

The 7-membered ring is disordered over 2 orientations (80:20\%). The disorder was modelled with partial occupancy atoms and it indicates that the 7-membered ring was "breathing" by moving from less hindered to more hindered confirmation which facilitate the migration of tosyl group in substitution reactions. The tosyl group in $\mathbf{8}$ and $\mathbf{9}$ were shown to be fluxional and undergo thermally-induced shift between the two thujaplicin oxygen atoms. Molecular mechanics calculations by the MMFF94 force field suggests that this process takes place most likely through bipyramidal intermediate. ${ }^{20}$

6-Isopropyl-thiotropolone (10) and 4-isopropyl-thiotropolone (11) were readily accessible in good yields by reacting $\mathbf{8}$ and $\mathbf{9}$ with sodium hydrosulfide in ethanol at room temperature (Scheme 2). The structures of $\mathbf{1 0}$ and $\mathbf{1 1}$ were fully assigned using 1D and 2D NMR spectroscopy.

2-Hydroxy-2,4,6-cycloheptatrien-1-one (tropolone 12) possesses hydroxyl group alpha to the carbonyl group and is expected to exhibit keto-enol tautomerism. Interestingly, this compound exists almost exclusively in the enol form (12A), which possess resonance stabilization because of its aromaticity. Density functional theory calculations of the keto-enol

A.<smiles>[B]C(C)c1cccc([O-])c(=O)c1</smiles>

B.

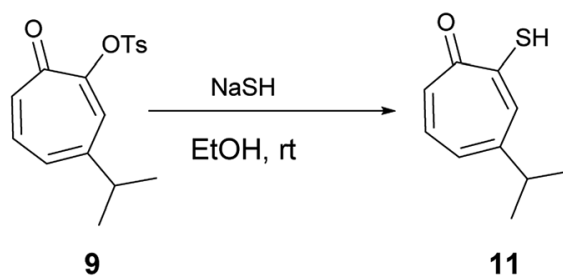

Scheme 2 Synthesis of 6-isopropyl-thiotropolone (10) and 4-isopropyl-thiotropolone (11). 
<smiles>O=c1cccccc1O</smiles><smiles>O=C1C=CC=CCC1=O</smiles>

12B

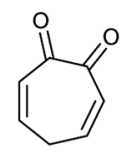

12C

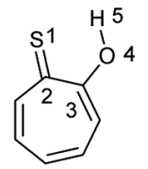

13A

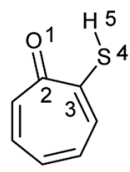

13B

Fig. 4 Hydroxytropolone tautomers $(12 \mathrm{~A}-\mathrm{C})$ and mercapto tropolone tautomers (13A and B).

equilibrium constants of 2-hydroxy-2,4,6-cycloheptatrien-1-one (12A) and 3,5- and 3,6-cycloheptadiene-1,2-dione (12B and 12C) showed that the equilibrium is tilted in favour of the enol (12A) (Fig. 4). ${ }^{21}$

The corresponding thiotropolones have seven possible tautomers. The tautomeric equilibrium of all tautomers of thiotropolone was studied using Hartree Fock (HF) and density functional theory (B3LYP) at different levels of theory. ${ }^{22}$ Calculating electronic energy and Gibbs free energy showed that the enol forms were more stable than the keto forms because of its aromaticity. This observation was supported by calculating the nucleus independent chemical shifts of NMR chemical shifts of the studied thiotropolones. ${ }^{22}$ Compound 13A (2-hydroxy-2,4,6cycloheptatriene-1-thione) was the most stable followed by compound 13B (2-mercapto-2,4,6-cycloheptatrien-1-one). The low energy of these two isomers is attributed to the favourable interactions between $\mathrm{H} 5-\mathrm{S} 1$ in $\mathbf{1 3 A}$ and $\mathrm{H} 5-\mathrm{O} 1$ in $\mathbf{1 3 B}{ }^{22}$

Nozoe $e t a l{ }^{23}$ was the first to synthesize 2-mercaptotropone and it was suggested to exist in two tautomeric forms. Sulfursubstituted derivatives were obtained upon alkylation and acylation of this compound, which suggests that 2-mercaptotropone (13B) is the prevailing tautomer. However, studying the physicochemical properties of 2-mercaptotropone and its structural analogues 6-isopropyl-2-mercaptotropone (10) and 4isopropyl-2-mercaptotropone (11) in depth suggested that the major tautomer is the 2-hydroxyl tropothione (13A). ${ }^{24}$

Table 2 Experimental and calculated ${ }^{1} \mathrm{H}$ and ${ }^{13} \mathrm{C}$ NMR chemical shifts (ppm) of compound 10

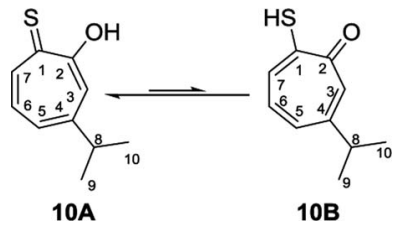

\begin{tabular}{|c|c|c|c|c|c|c|c|}
\hline Atom & $\delta_{\operatorname{Exp}} 10 \mathbf{A}$ & $\delta_{\text {Calc }} 10 \mathrm{~A}$ & $\delta_{\text {Calc }} 10 \mathrm{~B}$ & Atom & $\delta_{\operatorname{Exp}} \mathbf{1 0 A}$ & $\begin{array}{l}\delta_{\text {Calc }} \\
\mathbf{1 0 A}\end{array}$ & $\begin{array}{l}\delta_{\text {Calc }} \\
10 B\end{array}$ \\
\hline C-1 & 183.4 & 210.3 & 180.0 & $\mathrm{H}-3$ & 7.45 & 6.71 & 7.48 \\
\hline $\mathrm{C}-2$ & 172.5 & 179.0 & 185.9 & $\mathrm{H}-4$ & - & - & - \\
\hline C-3 & 119.6 & 118.2 & 141.2 & $\mathrm{H}-5$ & 7.21 & 6.98 & 7.07 \\
\hline C-4 & 161.2 & 164.9 & 164.1 & H-6 & 7.14 & 6.88 & 7.18 \\
\hline C-5 & 132.1 & 132.6 & 133.9 & $\mathrm{H}-7$ & 8.45 & 8.98 & 8.08 \\
\hline C-6 & 133.8 & 130.9 & 136.8 & $\mathrm{H}-8$ & 2.91 & 2.62 & 2.91 \\
\hline C-7 & 143.0 & 159.8 & 130.8 & $\mathrm{H}_{3}-9$ & 1.27 & 1.46 & 1.42 \\
\hline C-8 & 38.8 & 47.8 & 47.9 & $\mathrm{H}_{3}-10$ & 1.27 & 1.45 & 1.47 \\
\hline C-9 & 23.4 & 26.9 & 25.2 & $\mathrm{OH}$ or $\mathrm{SH}$ & 9.50 & 8.98 & 4.04 \\
\hline C-10 & 23.4 & 24.3 & 24.0 & & & & \\
\hline
\end{tabular}
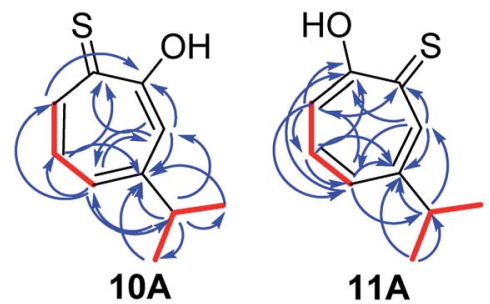

$={ }^{1} \mathrm{H}-{ }^{1} \mathrm{H}$ COSY

HMBC

Fig. 5 Key ${ }^{1} \mathrm{H}-{ }^{1} \mathrm{H}$ COSY and $\mathrm{HMBC}$ correlations of $10 \mathrm{~A}$ and $11 \mathrm{~A}$.

Compound 10 was obtained as a dark red oil. Its molecular formula $\left(\mathrm{C}_{10} \mathrm{H}_{11} \mathrm{OS}\right)_{2} \mathrm{Na}^{+}$was determined by HRESIMS data $(\mathrm{m} / \mathrm{z}$ 381.0951 $\left[\mathrm{M}_{2}+\mathrm{Na}\right]^{+}$, calc. 381.0953). The ${ }^{1} \mathrm{H}$ NMR showed that this compound exist in $\mathrm{CDCl}_{3}$ as two tautomers $10 \mathrm{~A}(\approx 87 \%)$ and $10 \mathrm{~B}(\approx 13 \%)$. We were able to fully assign the chemical shifts of the major tautomer 10A (Table 2). The analysis of ${ }^{1} \mathrm{H}$, ${ }^{13} \mathrm{C}$, COSY, HSQC, and HMBC spectra revealed the presence of a singlet proton $\mathrm{H}-3\left(\delta_{\mathrm{C}} / \delta_{\mathrm{H}} 119.6 / 7.45, \mathrm{C}-3\right)$. This proton shows two bond correlations with $\mathrm{C}-2\left(\delta_{\mathrm{C}} 172.5\right)$ and $\mathrm{C}-4\left(\delta_{\mathrm{C}} 161.2\right)$ and strong three bond correlations with C-1 $\left(\delta_{\mathrm{C}} 183.4\right), \mathrm{C}-5\left(\delta_{\mathrm{C}} 132.1\right)$ and $\mathrm{C}-8\left(\delta_{\mathrm{C}} 38.8\right)$. Furthermore, the one methine septet $\mathrm{H}-8\left(\delta_{\mathrm{C}} /\right.$ $\left.\delta_{\mathrm{H}} 38.8 / 2.91, \mathrm{C}-8\right)$ shows two bond correlations to C-4, C-9 and C$10\left(\delta_{\mathrm{C}} 23.4\right)$ and three bond correlations to C- 3 and C-5. The twomethyl doublet $\mathrm{H}_{3}-9$ and $\mathrm{H}_{3}-10\left(\delta_{\mathrm{C}} / \delta_{\mathrm{H}} 23.4 / 1.27\right.$, C-9 and C-10) shows two bond correlations to $\mathrm{C}-8$ and a strong three bond correlation to C-4. H-5 $\left(\delta_{\mathrm{C}} / \delta_{\mathrm{H}} 132.1 / 7.21, \mathrm{C}-5\right)$ shows two bond correlations to $\mathrm{C}-6$, and strong three bond correlations to $\mathrm{C}-3, \mathrm{C}-$ 7 and C-8. H-6 $\left(\delta_{\mathrm{C}} / \delta_{\mathrm{H}} 133.8 / 7.14, \mathrm{C}-3\right)$ shows strong three bond correlations to $\mathrm{C}-1$ and $\mathrm{C}-4 . \mathrm{H}-7\left(\delta_{\mathrm{C}} / \delta_{\mathrm{H}} 143.0 / 8.45, \mathrm{C}-7\right)$ shows strong three bond correlations to C-2 and C-5 (Fig. 5).

A.

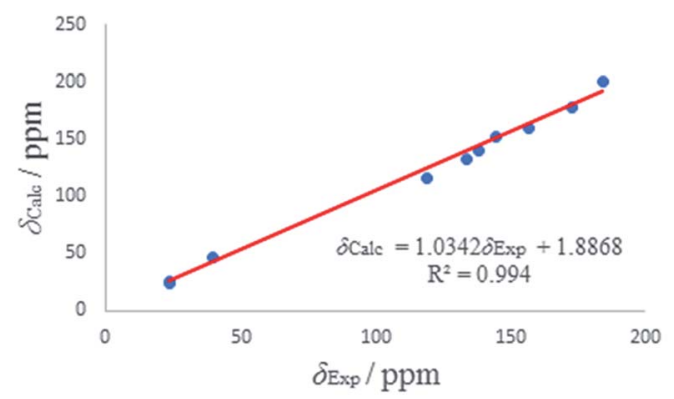

B.

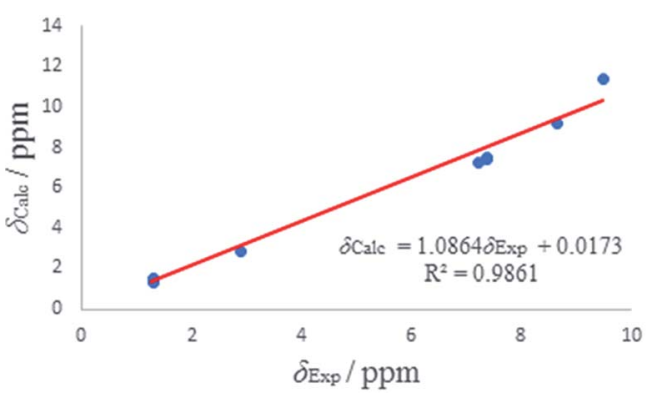

Fig. 6 (A) Experimental ${ }^{13} \mathrm{C}$ chemical shifts $(\delta)$ of $10 \mathrm{~A}(v s$.) calculated. (B) Experimental ${ }^{1} \mathrm{H}$ chemical shifts $(\delta)$ of $10 \mathrm{~A}$ (vs.) calculated. 
Table 3 Experimental and calculated ${ }^{1} \mathrm{H}$ and ${ }^{13} \mathrm{C}$ NMR chemical shifts (ppm) of compound 11

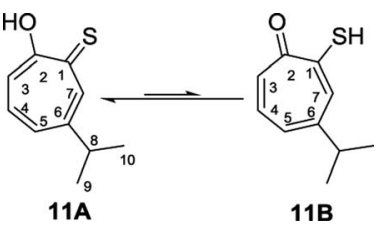

\begin{tabular}{|c|c|c|c|c|c|c|c|}
\hline Atom & $\delta_{\operatorname{Exp}} 11 \mathrm{~A}$ & $\delta_{\text {Calc }} 11 \mathrm{~A}$ & $\delta_{\text {Calc }}$ 11B & Atom & $\delta_{\operatorname{Exp}} 11 \mathrm{~A}$ & $\delta_{\text {Calc }} 11 \mathbf{A}$ & $\delta_{\text {Calc }} \mathbf{1 1 B}$ \\
\hline C-1 & 184.1 & 202.0 & 181.5 & $\mathrm{H}-3$ & 7.34 & 7.50 & 7.29 \\
\hline C-2 & 172.2 & 179.8 & 185.5 & $\mathrm{H}-4$ & 7.35 & 7.54 & 7.51 \\
\hline C-4 & 137.9 & 142.0 & 140.4 & $\mathrm{H}-6$ & - & - & - \\
\hline C-5 & 133.0 & 134.3 & 131.1 & $\mathrm{H}-7$ & 8.62 & 9.32 & 8.27 \\
\hline C-6 & 156.5 & 161.1 & 163.3 & $\mathrm{H}-8$ & 2.88 & 2.94 & 2.91 \\
\hline C-9 & 23.1 & 26.4 & 24.0 & $\mathrm{OH}$ or $\mathrm{SH}$ & 9.47 & 11.46 & 4.10 \\
\hline C-10 & 23.1 & 25.4 & 28.1 & & & & \\
\hline
\end{tabular}

We have calculated both ${ }^{1} \mathrm{H}$ and ${ }^{13} \mathrm{C}$ isotropic chemical shielding of $10 \mathrm{~A}$ and $\mathbf{1 0 B}$ at the B3LYP/def2-TZVPP level of theory. Correlation plots between experimental and calculated chemical shifts shows very good correlations in case of 10A with $R^{2}$ of 0.9828 and 0.99 for ${ }^{13} \mathrm{C}$ and ${ }^{1} \mathrm{H}$ NMR chemical shifts, respectively (Fig. 6). The calculated chemical shift values of isomer 10B correlated to less extent with the experimental values (see Fig. S52†).

Compound $\mathbf{1 1}$ was obtained as orange microcrystals. Its molecular formula $\left(\mathrm{C}_{10} \mathrm{H}_{11} \mathrm{OS}\right)_{2} \mathrm{Na}^{+}$was determined by HRESIMS data $\left(\mathrm{m} / \mathrm{z} 381.0950\left[\mathrm{M}_{2}+\mathrm{Na}\right]^{+}\right.$, calc. 381.0953$)$. This compound exists in $\mathrm{CDCl}_{3}$ as a mixture of two tautomers $11 \mathrm{~A}(\approx 96 \%)$ and 11B $(\approx 4 \%)$. We were able to fully assign the chemical shifts of the major tautomer 11A (Table 3). The analysis of ${ }^{1} \mathrm{H},{ }^{13} \mathrm{C}, \mathrm{COSY}$, HSQC, and HMBC spectra revealed the presence of a singlet proton $\mathrm{H}-7\left(\delta_{\mathrm{C}} / \delta_{\mathrm{H}} 144.0 / 8.62, \mathrm{C}-7\right)$. This proton shows two bond correlations with $\mathrm{C}-1\left(\delta_{\mathrm{C}} 184.1\right)$ and C-6 $\left(\delta_{\mathrm{C}}\right.$ 156.5) and strong three bond correlations with $\mathrm{C}-2\left(\delta_{\mathrm{C}} 172.2\right)$ and $\mathrm{C}-5\left(\delta_{\mathrm{C}} 133.0\right)$. Furthermore, the one methine septet $\mathrm{H}-8\left(\delta_{\mathrm{C}} / \delta_{\mathrm{H}} 39.0 / 2.88, \mathrm{C}-8\right)$ shows two bond correlations to C- $6\left(\delta_{\mathrm{C}} 156.5\right)$ and three bond correlations to C-7. The two-methyl doublet $\mathrm{H}_{3}-9$ and $\mathrm{H}_{3}-10\left(\delta_{\mathrm{C}} / \delta_{\mathrm{H}}\right.$ 23.1/1.27, C-9 and C-10) shows two bond correlations to C-8 and a strong three bond correlation to C-6. H-5 $\left(\delta_{\mathrm{C}} / \delta_{\mathrm{H}} 133.0 / 7.19, \mathrm{C}-5\right)$ shows two bond correlations to $\mathrm{C}-6$, strong three bond correlations to C-3 and C-8, and four bond correlations to C-2. $\mathrm{H}-3\left(\delta_{\mathrm{C}} / \delta_{\mathrm{H}}\right.$ 118.2/7.34, C-3) shows two bond correlations to C-2 and C-4 and strong three bond correlations to C- 1 and C-5. $\mathrm{H}-4\left(\delta_{\mathrm{C}} / \delta_{\mathrm{H}} 137.9 /\right.$ $7.35, \mathrm{C}-4)$ shows two bond correlations to $\mathrm{C}-5$ and strong three bond correlations to C-2 and C- 6 which further confirms the location of the isopropyl groups (Fig. 5).

${ }^{1} \mathrm{H}$ and ${ }^{13} \mathrm{C}$ isotropic chemical shielding of $\mathbf{1 1 A}$ and $\mathbf{1 1 B}$ were calculated at the B3LYP/def2-TZVPP level of theory (Table 3). Correlation plots between experimental and calculated chemical shifts shows very good correlations in the case of $11 \mathrm{~A}$, with $R^{2}$ of 0.994 and 0.9861 for ${ }^{13} \mathrm{C}$ and ${ }^{1} \mathrm{H}$ NMR chemical shifts, respectively (Fig. 7). The calculated
A.

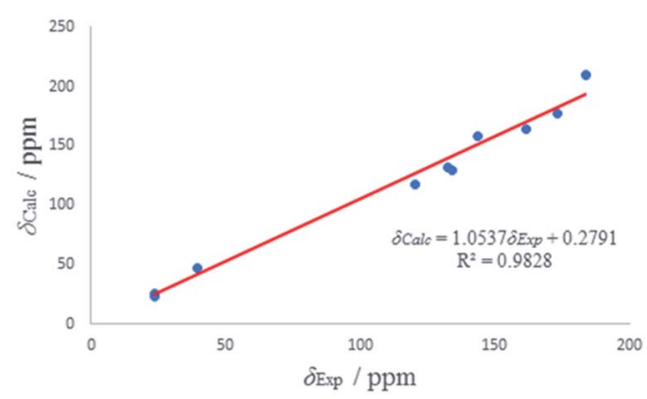

B.

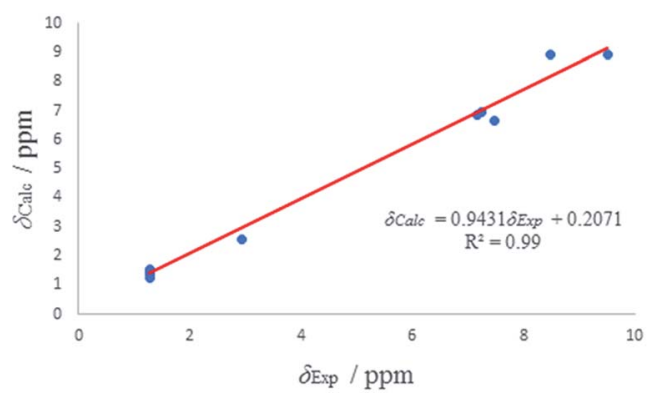

Fig. 7 (A) Experimental ${ }^{13} \mathrm{C}$ chemical shifts $(\delta)$ of $11 \mathrm{~A}$ (vs.) calculated. (B) Experimental ${ }^{1} \mathrm{H}$ chemical shifts $(\delta)$ of $11 \mathrm{~A}$ (vs.) calculated.

chemical shift values of isomer 11B correlated to less extent with the experimental values (see Fig. S53†).

\section{Computational details}

Electronic structure calculations were performed using ORCA. ${ }^{25,26}$ Crystal structures of compounds $\mathbf{8}$ and $\mathbf{9}$ were optimized at the DFT theory BLYP with basis sets deft2-SVP and RI approximation. Geometries of compounds 10 and 11, and their isomers were modelled using the Avogadro program. ${ }^{27}$ Their geometries were 
Table $4 \mathrm{MIC}_{80}$ and $\mathrm{CC}_{50}$ values against E. coli, S. aureus, A. baumannii, P. aeruginosa, and C. neoformans

\begin{tabular}{|c|c|c|c|c|c|c|c|}
\hline \multirow[b]{2}{*}{ Comp. } & \multicolumn{4}{|c|}{ Bacteria $\mathrm{MIC}_{80}(\mu \mathrm{M})$} & \multirow[b]{2}{*}{$\begin{array}{l}\text { C. neoformans } \\
\mathrm{MIC}_{80}\end{array}$} & \multicolumn{2}{|l|}{$\mathrm{CC}_{50}$} \\
\hline & $\begin{array}{l}\text { S. aureus } \\
(29213)\end{array}$ & $\begin{array}{l}\text { E. coli } \\
(35218)\end{array}$ & $\begin{array}{l}\text { A. baumannii } \\
\text { (from a patient) }\end{array}$ & $\begin{array}{l}\text { P. aeruginosa } \\
(27853)\end{array}$ & & $\begin{array}{l}\mathrm{CC}_{50} \\
\text { (neutral red) }\end{array}$ & $\mathrm{CC}_{50}$ (MTS) \\
\hline $2^{4}$ & 66.7 & 44.4 & 51.2 & $>100$ & 21 (ref. 4) & na & 66.4 \\
\hline 8 & $>100$ & $>100$ & $>100$ & $>100$ & 24 & 31.8 & 33.6 \\
\hline 9 & 8.8 & $>100$ & $>100$ & $>100$ & 24 & 19.5 & 34.2 \\
\hline 10 & $>100$ & $>100$ & $>100$ & $>100$ & 50 & 39.7 & 95 \\
\hline 11 & 16 & $>100$ & $>100$ & $>100$ & 24 & 30.4 & 64.2 \\
\hline
\end{tabular}

Table 5 Calculated molecular descriptors for prediction of ADME properties for each compound. Recommended values or range for $95 \%$ of known drugs is shown in parenthesis

\begin{tabular}{|c|c|c|c|c|c|c|c|c|c|c|c|}
\hline Comp. & ${ }^{a}$ mol_MW & ${ }^{b} \mathrm{QP} \log \mathrm{Po} / \mathrm{w}$ & ${ }^{c} \mathrm{HBD}$ & ${ }^{d} \mathrm{HBA}$ & $\begin{array}{l}{ }^{e_{\%}} \% \text { Human } \\
\text { oral absorption }\end{array}$ & $f_{\mathrm{PSA}}$ & ${ }^{g}$ Qp $\log \mathrm{S}$ & ${ }^{h}$ QPPCaco & ${ }^{i} \#$ Metab & ${ }^{j} \mathrm{Qp} \log \mathrm{BB}$ & ${ }^{k} \mathrm{QPPMDCK}$ \\
\hline 2 & 164.204 & 1.443 & 1 & 2.75 & 89.394 & 50.125 & -2.193 & 1040.346 & 2 & -0.396 & 516.318 \\
\hline 8 & 318.387 & 2.1 & 0 & 6.5 & 92.748 & 68.778 & -2.742 & 975.826 & 2 & -0.615 & 490.424 \\
\hline 9 & 318.387 & 2.216 & 0 & 6.5 & 94.321 & 68.77 & -2.952 & 1095.291 & 2 & -0.591 & 555.56 \\
\hline 10A & 180.264 & 2.351 & 0.8 & 2.5 & 100 & 28.102 & -2.794 & 3286.638 & 2 & 0.207 & 4437.612 \\
\hline 10B & 180.264 & 2.4 & 1 & 2.25 & 100 & 29.939 & -2.881 & 3010.296 & 2 & 0.168 & 3962.203 \\
\hline 11A & 180.264 & 2.36 & 0.8 & 2.5 & 100 & 28.166 & -2.843 & 3222.618 & 2 & 0.195 & 4334.35 \\
\hline 11B & 180.264 & 2.398 & 1 & 2.25 & 100 & 30.01 & -2.884 & 2998.094 & 2 & 0.166 & 3935.7 \\
\hline
\end{tabular}

${ }^{a}$ Molar weight in Daltons (130-725). ${ }^{b}$ Logarithm of partitioning coefficient between $n$-octanol and water phases (range for $95 \%$ of drugs: -2 to 6). ${ }^{c}$ Number of hydrogen bonds donors (0-6). ${ }^{d}$ Number of hydrogen bond acceptors $(2-20) .{ }^{e}$ Predicted human oral absorption on a $0-100 \%$ scale, based on a multiple linear regression model $\left(<25 \%\right.$ low, $>80 \%$ high). ${ }^{f}$ Polar surface area $(7-200) .{ }^{g}$ Predicted aqueous solubility, log S. S in mol $\mathrm{dm}^{-3}$ (-6.5 to 0.5). ${ }^{h}$ Predicted apparent Caco-2 cell permeability in $\mathrm{nm} \mathrm{s} \mathrm{s}^{-1}$ as a model for the gut-blood barrier $(<25$ poor, $>500$ excellent). ${ }^{i}$ Number of possible metabolic reactions $(2-8) .{ }^{j}$ Predicted brain/blood partition coefficient ( -3 to 1.2$) .{ }^{k}$ Predicted apparent MDCK cell permeability in $\mathrm{nm} \mathrm{s}^{-1}$ as a mimic for blood/brain barrier (<25 poor, $>500$ excellent). Qikrop predictions are for non-active transport.

optimized at the B3LYP functional ${ }^{28,29}$ and def2-TZVPP basis set. ${ }^{30}$ The RijCosX approximation and deft2/J auxiliary basis set were used during optimization. The absolute ${ }^{1} \mathrm{H}$ NMR chemical shifts $\left(\delta_{\mathrm{H}}\right),{ }^{13} \mathrm{C}$ NMR chemical shifts $\left(\delta_{\mathrm{C}}\right)$ for all compounds were calculated with the GIAO (Gauge Including Atomic Orbitals) method $^{31-33}$ at B3LYP def2-TZVPP level of theory. The TMS shielding was calculated at the same level of theory and relative chemical shifts were then estimated by subtracting the calculated chemical shift from TMS. The calculated ${ }^{1} \mathrm{H}$ and ${ }^{13} \mathrm{C}$ isotropic chemical shielding of TMS are 31.942/183.923.

\section{Biological evaluation}

The broad anti-bacterial activity of $\beta$-thujaplicin (Hinokitiol, 2) was reported several decades ago. ${ }^{34,35}$ Compound 2 could modestly inhibit $S$. aureus, E. coli, and A. baumannii in our experimental conditions, with $\mathrm{MIC}_{80}$ values of $66.7,44.4$ and 51.2 $\mu \mathrm{M}$, respectively. Compound $\mathbf{8}$, which is the rearranged tosyl isomer of the natural product 2 , has no activity against all tested bacteria $\left(\mathrm{MIC}_{80}>100 \mu \mathrm{M}\right)$. However, this compound showed similar activity to 2 against C. neoformans $\left(\mathrm{MIC}_{80}=24 \mu \mathrm{M}\right.$ for $8 v$ s. $\mathrm{MIC}_{80}=21 \mu \mathrm{M}$ for 2). Interestingly, compound 9, which is the tosylated derivative of the natural product 2 showed 8 -fold increase in the antibacterial activity against $S$. aureus, but diminished activity against the Gram-negative bacteria E. coli, A. baumannii, and $P$. aeruginosa. Compound 9 has similar activity to 2 and 8 against $C$. neoformans $\left(\mathrm{MIC}_{80}=24 \mu \mathrm{M}\right)($ Table 4$)$.
The mercapto derivative of $\mathbf{8}$, compound $\mathbf{1 0}$, has no antibacterial activity against all four tested bacteria. The activity of 10 against $C$. neoformans $\left(\mathrm{MIC}_{80}=50 \mu \mathrm{M}\right)$ is $>2$-fold less than the corresponding hydroxy tropolone 2 . The mercapto derivative of $\mathbf{9}$, compound $\mathbf{1 1}$, which is the direct isomer of $\mathbf{2}$, showed promising antibacterial activity against $S$. aureus $\left(\mathrm{MIC}_{80}=16\right.$ $\mu \mathrm{M})$, but no activity against the other tested bacteria. Compound $\mathbf{1 1}$ showed similar activity as 2, 8, and $\mathbf{9}$ against $C$. neoformans $\left(\mathrm{MIC}_{80}=24 \mu \mathrm{M}\right)$ (Table 4$)$.

We tested the cytotoxicity of the synthesized compounds in hepatoblastoma cells using an MTS cytotoxicity assay that measures mitochondrial function and a neutral red assay that measures lysosomal function and calculated the $\mathrm{CC}_{50}$, which is the concentration of inhibitor required to reduce cell viability $50 \%$ relative to untreated cells (Table 4). Compound 10 have the lowest toxicity among all synthesized compounds in both assays. The toxicity of compound $\mathbf{1 1}$ is relatively low, and comparable to the natural product $\beta$-thujaplicin (2).

\section{In silico ADME evaluation}

We calculated a set of physical descriptors and pharmaceutical properties of all tested compounds using Qikprop to predict their absorption, distribution, metabolism, and excretion (ADME) properties (Table 5). All compounds are in compliance with Lipinski's rule of five ${ }^{36}$ and Jorgensen's rule of three ${ }^{37}$ and 
are predicted to have good oral bioavailability and excellent absorption through cell membranes.

\section{Conclusions}

Tosylated thujaplicin isomers $\mathbf{8}$ and $\mathbf{9}$ were separated for the first time and their structures were fully characterized. Isomers $\mathbf{8}$ and 9 were used to synthesize the two mercapto isomers of $\beta$-thujaplicin, 10 and 11, in a regioselective manner. ${ }^{1} \mathrm{H}$ and ${ }^{13} \mathrm{C}$ Chemical shifts of synthesized isomers were fully assigned using several NMR experiments, and their isotropic magnetic shielding was calculated computationally. The calculated chemical shift values were in a good agreement with the experimental results. When the biological activity of the synthesized compounds was evaluated against $C$. neoformans and four different bacterial strains, 4-isopropyl-thiotropolone (11) displayed good potency against Staphylococcus aureus (ATCC 29213). The relatively nontoxic nature of this compound and excellent predicted ADME properties make it a potential lead compound to develop potent inhibitors against Staphylococcus aureus infection.

\section{Experimental section}

All materials were purchased from commercial suppliers and used without further purification. Purification was done by Reveleris X2 flash chromatography. The purities of the final compounds were characterized by high-performance liquid chromatography (HPLC) using a gradient elution program (Ascentis Express Peptide C18 column, acetonitrile/water 5/95 $\rightarrow$ 95/5, $5 \mathrm{~min}, 0.05 \%$ trifluoracetic acid) and UV detection (254 nM). The purities of final compounds were $95 \%$ or greater. NMR spectra was recorded on a Bruker NMR $400 \mathrm{MHz}$ Avance III spectrometer operating at $400 \mathrm{MHz}$ for ${ }^{1} \mathrm{H}$ NMR and $100 \mathrm{MHz}$ for ${ }^{13} \mathrm{C}$ NMR. Chemical shifts are given in part per million (ppm) relative to tetramethylsilane (TMS), coupling constants $J$ are given in Hertz. High-resolution mass spectra were obtained using electrospray ionization on a Bruker $12 \mathrm{~T}$ APEX-Qe FTICR-MS with an Apollo II ion source at the COSMIC Laboratory facility at Old Dominion University, VA.

\section{Synthesis of compounds 8 and 9}

$p$-Toluenesulfonyl chloride $(2.3 \mathrm{~g}, 12.2 \mathrm{mmol})$ was added to a solution of tropolone $(2 \mathrm{~g}, 12.2 \mathrm{mmol})$ and DIPEA ( $4.3 \mathrm{~mL}, 24.4$ $\mathrm{mmol})$ in DCM $(50 \mathrm{~mL})$, and the reaction mixture was stirred overnight. The resulting mixture was successively washed with $1 \mathrm{M} \mathrm{HCl}(30 \mathrm{~mL})$, water $(30 \mathrm{~mL})$ and brine $(30 \mathrm{~mL})$. The organic layer was dried over $\mathrm{Na}_{2} \mathrm{SO}_{4}$, filtered and the solvent was evaporated in vacuo yielding a mixture of the two isomers, which were separated by flash chromatography using (EtOAc/hexanes $3: 7$ ) with a flow rate $10 \mathrm{~mL} \mathrm{~min}{ }^{-1}$ to obtain each isomer in a pure form.

6-(1-Methylethyl)-2-[[(4-methylphenyl)sulfonyl $]$ oxy $]-2,4,6-$ cycloheptatrien-1-one (8)

White needles ( $46 \%), R_{\mathrm{f}}=0.655(\mathrm{EtOAc} /$ hexanes $1: 1) .{ }^{1} \mathrm{H}$ NMR $(400 \mathrm{MHz}$, chloroform- $d$ ) $\delta 7.92(\mathrm{~d}, J=7.3 \mathrm{~Hz}, 2 \mathrm{H}), 7.38-7.26(\mathrm{~m}$,
3H), $7.08(\mathrm{~s}, 1 \mathrm{H}), 7.01(\mathrm{~d}, J=11.4 \mathrm{~Hz}, 1 \mathrm{H}), 6.91(\mathrm{t}, J=10.3 \mathrm{~Hz}$, $1 \mathrm{H}), 2.82-2.67(\mathrm{~m}, 1 \mathrm{H}), 2.44(\mathrm{~s}, 3 \mathrm{H}), 1.20(\mathrm{~d}, J=6.7 \mathrm{~Hz}, 6 \mathrm{H}) ;{ }^{13} \mathrm{C}$ NMR (100 MHz, chloroform- $d$ ) $\delta$ 179.2, 157.5, 154.6, 145.4, 137.8, 136.7, 133.5, 129.7, 129.6, 129.3, 128.6, 38.4, 22.7, 21.8; LC/MS $m / z: 319.1[\mathrm{M}+\mathrm{H}]^{+}, 341[\mathrm{M}+\mathrm{Na}]^{+}$. HRESIMS $\mathrm{m} / \mathrm{z}$ $341.0816[\mathrm{M}+\mathrm{Na}]^{+}$(calcd for $\mathrm{C}_{17} \mathrm{H}_{18} \mathrm{O}_{4} \mathrm{SNa}^{+}, 341.0818$ ).

\section{4-(1-Methylethyl)-2-[[(4-methylphenyl)sulfonyl] oxy]-2,4,6- cycloheptatrien-1-one (9)}

White powder $(43 \%), R_{\mathrm{f}}=0.483($ EtOAc/hexanes $1: 1) .{ }^{1} \mathrm{H}$ NMR $(400 \mathrm{MHz}$, chloroform- $d) \delta 7.93(\mathrm{~d}, J=7.6 \mathrm{~Hz}, 2 \mathrm{H}), 7.41-7.32(\mathrm{~m}$, $3 \mathrm{H}), 7.17(\mathrm{dd}, J=12.1,8.7 \mathrm{~Hz}, 1 \mathrm{H}), 7.04(\mathrm{~d}, J=12.3 \mathrm{~Hz}, 1 \mathrm{H}), 6.96$ $(\mathrm{d}, J=8.6 \mathrm{~Hz}, 1 \mathrm{H}), 2.89-2.75(\mathrm{~m}, 1 \mathrm{H}), 2.46(\mathrm{~s}, 3 \mathrm{H}), 1.24(\mathrm{~d}, J=$ $6.8 \mathrm{~Hz}, 6 \mathrm{H}) ;{ }^{13} \mathrm{C}$ NMR $(100 \mathrm{MHz}$, chloroform-d) $\delta$ 178.9, 154.5, 152.4, 145.5, 139.0, 136.9, 133.4, 131.8, 130.5, 129.6, 128.6, 38.1, 22.8, 21.8; LC/MS $m / z: 319.1[\mathrm{M}+\mathrm{H}]^{+}, 341[\mathrm{M}+\mathrm{Na}]^{+}$. HRESIMS $m / z 341.0815[\mathrm{M}+\mathrm{Na}]^{+}$(calcd for $\mathrm{C}_{17} \mathrm{H}_{18} \mathrm{O}_{4} \mathrm{SNa}^{+}$, 341.0818).

\section{General procedure for the synthesis of $\mathbf{1 0}$ and 11}

$\mathrm{NaSH}(0.122 \mathrm{~g}, 2.17 \mathrm{mmol})$ was added portion wise to a solution of 8 or $9(0.150 \mathrm{~g}, 0.54 \mathrm{mmol})$ in ethanol $(10 \mathrm{~mL})$. The reaction mixture was stirred for $2 \mathrm{~h}$ at room temperature and was monitored by LCMS and TLC till completion. Ethanol was evaporated, and the resulting solid was dissolved in water and acidified with $\mathrm{HCl}(2 \mathrm{M})$ then extracted with DCM $(3 \times 20 \mathrm{~mL})$ to yield the desired product. Purification was performed by flash chromatography using a mixture of EtOAc/hexanes to obtain the desired compound.

\section{2-Hydroxy-4-isopropylcyclohepta-2,4,6-triene-1-thione (10)}

Red dark oil, $R_{\mathrm{f}}=0.876$ (EtOAc/hexanes $\left.1: 1\right) .{ }^{1} \mathrm{H}$ NMR (400 $\mathrm{MHz}$, chloroform- $d) \delta 9.71(\mathrm{~s}, 1 \mathrm{H}), 8.46(\mathrm{~d}, J=10.6 \mathrm{~Hz}, 1 \mathrm{H}), 7.47$ (s, 1H), $7.23(\mathrm{~d}, J=9.7 \mathrm{~Hz}, 1 \mathrm{H}), 7.16(\mathrm{t}, J=10.2 \mathrm{~Hz}, 1 \mathrm{H}), 2.99-$ $2.87(\mathrm{~m}, 1 \mathrm{H}), 1.29(\mathrm{~d}, J=6.9 \mathrm{~Hz}, 7 \mathrm{H}) ;{ }^{13} \mathrm{C}$ NMR $\left(101 \mathrm{MHz}, \mathrm{CDCl}_{3}\right)$ $\delta$ 183.5, 172.5, 161.4, 143.1, 134.0, 132.2, 119.7, 38.9, 23.5; LC/ MS $m / z: 181[\mathrm{M}+\mathrm{H}]^{+}$. HRESIMS $m / z 381.0951\left[\mathrm{M}_{2}+\mathrm{Na}\right]^{+}$ (calcd for $\left.\left(\mathrm{C}_{10} \mathrm{H}_{11} \mathrm{OS}\right)_{2} \mathrm{Na}^{+}, 381.0953\right)$.

\section{7-Hydroxy-3-isopropylcyclohepta-2,4,5-triene-1-thione (11)}

Orange crystal, $R_{\mathrm{f}}=0.793$, (EtOAc/hexanes $\left.1: 1\right) .{ }^{1} \mathrm{H}$ NMR $(400$ MHz, chloroform- $d$ ) $\delta 9.86(\mathrm{~s}, 1 \mathrm{H}), 8.63(\mathrm{~s}, 1 \mathrm{H}), 7.39-7.26(\mathrm{~m}, 2 \mathrm{H})$, 7.26-7.11 (m, 1H), 2.94-2.83 (m, 1H), $1.27(\mathrm{~d}, J=6.9 \mathrm{~Hz}, 6 \mathrm{H}) ;{ }^{13} \mathrm{C}$ NMR (101 MHz, $\left.\mathrm{CDCl}_{3}\right) \delta 184.3,172.2,156.6,144.1,138.0,133.1$, 118.3, 39.1, 23.5; LC/MS $m / z: 181[\mathrm{M}+\mathrm{H}]{ }^{+}$. HRESIMS $\mathrm{m} / \mathrm{z}$ $381.0950\left[\mathrm{M}_{2}+\mathrm{Na}\right]^{+}\left(\right.$calcd for $\left.\left(\mathrm{C}_{10} \mathrm{H}_{11} \mathrm{OS}\right)_{2} \mathrm{Na}^{+}, 381.0953\right)$.

\section{$\mathrm{X}$-ray structure determination of 8}

A crystals of approximate dimensions $0.544 \times 0.254 \times 0.132$ $\mathrm{mm}^{3}$ was mounted on a MiTeGen cryoloop in a random orientation. Preliminary examination and data collection were performed using a Bruker X8 Kappa Apex II Charge Coupled Device (CCD) Detector system single crystal X-ray diffractometer equipped with an Oxford Cryostream LT device. All data were collected using graphite monochromated Mo K radiation $(=0.71073 \AA)$ from a fine focus sealed tube X-ray source. 
Preliminary unit cell constants were determined with a set of 36 narrow frame scans. Typical data sets consist of combinations of and $\phi$ scan frames with typical scan width of 0.5 and counting time of 10 seconds per frame at a crystal to detector distance of $4.0 \mathrm{~cm}$. The collected frames were integrated using an orientation matrix determined from the narrow frame scans. Apex II and SAINT software packages (Bruker Analytical X-ray, Madison, WI, 2016) were used for data collection and data integration. Analysis of the integrated data did not show any decay. Final cell constants were determined by global refinement of 7781 reflections harvested from the complete data set. Collected data were corrected for systematic errors using SADABS (Bruker Analytical X-ray, Madison, WI, 2016) based on the Laue symmetry using equivalent reflections.

Crystal data and intensity data collection parameters are listed in Table 1S. $\uparrow$ Structure solution and refinement were carried out using the SHELXTL-PLUS software package. ${ }^{40}$ The structure was solved and refined successfully in the monoclinic space group $P 2_{1} / c$. Full matrix least-squares refinements were carried out by minimizing $\mathrm{w}\left(\mathrm{Fo}^{2}-\mathrm{Fc}^{2}\right)^{2}$. The non-hydrogen atoms were refined anisotropically to convergence. The 7membered ring is disordered, and the two orientations were refined with geometrical restraints to $82: 18 \%$. All hydrogen atoms were treated using appropriate riding model (AFIX m3). The final residual values and structure refinement parameters are listed in Table $1 \mathrm{S.} \dagger$

Complete listings of positional and isotropic displacement coefficients for hydrogen atoms, anisotropic displacement coefficients for the non-hydrogen atoms and other geometrical parameters are listed as ESI (Tables $2 \mathrm{~S}$ to $7 \mathrm{~S}^{\dagger}$ ). Table of calculated and observed structure factors are available in electronic format.

\section{Bacterial strains}

Staphylococcus aureus (ATCC 29213), Escherichia coli (ATCC 35218), and Pseudomonas aeruginosa (ATCC 27853) were obtained from the American Type Culture Collection (ATCC). Acinetobacter baumannii was collected from the microbiology laboratory at the John Cochran division of the St. Louis VA Medical Center (STLVAMC) under a Subcommittee on Research Safety (SRS)-approved protocol.

\section{Determination of the minimum inhibitory concentration}

$\mathrm{MIC}_{80} \mathrm{~S}$ were determined by the broth microdilution method recommended by the Clinical and Laboratory Standards Institute (CLSI) in cation-adjusted Mueller-Hinton II broth (CAMHB). A 1.5-fold dilution series of the compounds was prepared in CAMHB. Overnight bacterial culture was added to the diluted compounds in a 96 well plate after adjusting the bacterial concentration to $5 \times 10^{5} \mathrm{CFU} \mathrm{mL}^{-1}$ in final concentration. After $16-24$ hours incubation at $35{ }^{\circ} \mathrm{C} \pm 2{ }^{\circ} \mathrm{C}$, the plates were read at $600 \mathrm{nM}$ in microplate reader. The $\mathrm{MIC}_{80}$ was defined as the concentration of an antibacterial agent that inhibited bacteria growth $\geq 80 \%$ compared to vehicle-treated control cultures. All values were determined at least twice independently, and the average number is reported.

\section{Inhibition of $C$. neoformans growth}

Compounds were tested C. neoformans var grubii, KN99 (serotype A, MAT $\alpha$ ) in a limiting dilution assay with a starting optical density $(650 \mathrm{nM})$ of 0.001 in YNB-02 $(0.67 \%$ yeast nitrogen base, $0.2 \%$ dextrose, $\mathrm{pH} 7.0$ with $50 \mathrm{mM}$ MOPs) $+1 \%$ DMSO. Cells were incubated without shaking for 48 hours at $35{ }^{\circ} \mathrm{C}$ and cell density was measured at $650 \mathrm{nM}$. The minimal inhibitory concentration was determined using compound concentrations from 0.19 to $50 \mu \mathrm{M}$ of the compound in YNB-02 + 1\% DMSO. Each assay was done in triplicate and all values are the average of two or more independent assays. The data are presented as the average cell density as a percent of DMSO-only treated cells. MICs are reported as the minimal concentration needed to inhibit $80 \%$ of $C$. neoformans growth relative to vehicle-treated controls.

\section{Cytotoxicity in hepatoma cells}

HepDES19 cells $^{38}\left(1.0 \times 10^{4}\right.$ cells per well $)$ were seeded in 96well plates and incubated in Dulbecco's Modified Eagle Medium (DMEM) with 10\% FBS plus $1 \%$ penicillin/ streptomycin solution, $1 \%$ nonessential amino acids, and 1\% glutamine. The compounds were diluted in the medium to the desired concentrations at a final concentration of 1\% DMSO and added to the cells $48 \mathrm{~h}$ after plating, with each concentration tested in triplicate.

\section{MTS cytotoxicity assay $\left(\mathrm{CC}_{50}\right)$}

Soluble MTS reagent [3-(4,5-dimethylthiazol-2-yl)-5-(3-carboxymethoxyphenyl)-2-(4-sulfophenyl)-2 $H$-tetrazolium, Promega] was added $72 \mathrm{~h}$ after incubation, the cultures were incubated for $90 \mathrm{~min}$, and absorbance was read at $490 \mathrm{~nm}$. The $\mathrm{CC}_{50}$ was calculated as the concentration of inhibitor required to reduce cell viability $50 \%$ relative to untreated cells. The data are plotted as $\log$ [inhibitor] versus response and fit to a variable slope model using GraphPad Prism (v6, www.graphpad.com). ${ }^{4}$

\section{Neutral red assay $\left(\mathrm{CC}_{50}\right)$}

Cells were incubated with the compound for 72 hours and cytotoxicity was measured using a neutral red assay. ${ }^{39}$ The data were transformed to $\log [$ inhibitor] and fit to a 4 -variable slope curve using GraphPad Prism. The concentration at which 50\% of cells were inhibited relative to vehicle-treated control is reported as the $\mathrm{CC}_{50}$ value.

\section{Conflicts of interest}

There are no conflicts to declare.

\section{Acknowledgements}

This work was financially supported by Saint Louis University Start up fund (No. 203437). Funding from the National Science Foundation (MRI, CHE-0420497) for the purchase of the Apex-II diffractometer is acknowledged. We would like to thank Ms Ashley Anderson for help with acquiring NMR. 


\section{Notes and references}

1 M. Yamato, K. Hashigaki, Y. Yasumoto, J. Sakai, R. F. Luduena, A. Banerjee, S. Tsukagoshi, T. Tashiro and T. Tsuruo, J. Med. Chem., 1987, 30, 1897-1900.

2 K. Sugawara, M. Ohbayashi, K. Shimizu, M. Hatori, H. Kamei, M. Konishi, T. Oki and H. Kawaguchi, J. Antibiot., 1988, 41, 862-868.

3 M. Yamato, J. Ando, K. Sakaki, K. Hashigaki, Y. Wataya, S. Tsukagoshi, T. Tashiro and T. Tsuruo, J. Med. Chem., 1992, 35, 267-273.

4 M. J. Donlin, A. Zunica, A. Lipnicky, A. K. Garimallaprabhakaran, A. J. Berkowitz, A. Grigoryan, M. J. Meyers, J. E. Tavis and R. P. Murelli, Antimicrob. Agents Chemother., 2017, 61, e02574-16.

5 W. H. Johnston, J. J. Karchesy, G. H. Constantine and A. M. Craig, Phytother. Res., 2001, 15, 586-588.

6 S. R. Piettre, A. Ganzhorn, J. Hoflack, K. Islam and J. M. Hornsperger, J. Am. Chem. Soc., 1997, 119, 3201-3204.

7 D. M. Himmel, K. A. Maegley, T. A. Pauly, J. D. Bauman, K. Das, C. Dharia, A. D. Clark, K. Ryan, M. J. Hickey, R. A. Love, S. H. Hughes, S. Bergqvist and E. Arnold, Structure, 2009, 17, 1625-1635.

8 S. J. Newberry, J. D. FitzGerald, A. Motala, M. Booth, M. A. Maglione, D. Han, A. Tariq, C. E. O'Hanlon, R. Shanman, W. Dudley and P. G. Shekelle, Ann. Intern. Med., 2017, 166, 27-36.

9 S. Özen, E. D. Batu and S. Demir, Front. Immunol., 2017, 8, 253.

10 A. Bayes-Genis, Y. Adler, A. B. De Luna and M. Imazio, Eur. Heart J., 2017, 38, 1706-1709.

11 H. Yamano, T. Yamazaki, K. Sato, S. Shiga, T. Hagiwara, K. Ouchi and T. Kishimoto, Antimicrob. Agents Chemother., 2005, 49, 2519-2521.

12 A. Muzaffar, A. Brossi, C. M. Lin and E. Hamel, J. Med. Chem., 1990, 33, 567-571.

13 J. Guan, X. K. Zhu, Y. Tachibana, K. F. Bastow, A. Brossi, E. Hamel and K. H. Lee, J. Med. Chem., 1998, 41, 1956-1961.

14 S. Tsubotani, Y. Wada, K. Kamiya, H. Okazaki and S. Harada, Tetrahedron Lett., 1984, 25, 419-422.

15 K. Kintaka, H. Ono, S. Tsubotani, S. Harada and H. Okazaki, J. Antibiot., 1984, 37, 1294-1300.

16 I. Tamburlin-Thumin, M. P. Crozet, J. C. Barriere, M. Barreau, J. F. Riou and F. Lavelle, Eur. J. Med. Chem., 2001, 36, 561-568.
17 M. Cavazza and F. Pietra, Org. Biomol. Chem., 2003, 1, 30023003.

18 M. C. Barret, P. H. Bhatia, G. Kociok-Köhn and K. C. Molloy, Transition Met. Chem., 2014, 39, 543-551.

19 T. Yanagisawa, K. Kosakai, T. Tomiyama, M. Yasunami and K. Takase, Chem. Pharm. Bull., 1990, 38, 3355-3358.

20 M. Cavazza and F. Pietra, Tetrahedron Lett., 2003, 44, 18951897.

21 S. W. Paine and A. Salam, Chem. Phys., 2006, 331, 61-66.

22 S. W. Paine and A. Salam, Int. J. Quantum Chem., 2012, 113, 1245-1252.

23 T. Nozoe, M. Satô and K. Matsui, Proc. Jpn. Acad., 1953, 29, 22-26.

24 T. Nozoe and K. Matsui, Bull. Chem. Soc. Jpn., 1961, 34, 616618.

25 N. Frank, Wiley Interdiscip. Rev.: Comput. Mol. Sci., 2011, 2, 73-78.

26 N. Frank, Wiley Interdiscip. Rev.: Comput. Mol. Sci., 2017, 8, e1327.

27 M. D. Hanwell, D. E. Curtis, D. C. Lonie, T. Vandermeersch, E. Zurek and G. R. Hutchison, J. Cheminf., 2012, 4, 17.

28 A. D. Becke, J. Chem. Phys., 1986, 84, 4524-4529.

29 A. D. Becke, J. Chem. Phys., 1993, 98, 5648-5652.

30 F. Weigend and R. Ahlrichs, Phys. Chem. Chem. Phys., 2005, 7, 3297-3305.

31 F. London, J. Phys. Radium, 1937, 8, 397-409.

32 R. Ditchfield, J. Chem. Phys., 1972, 56, 5688-5691.

33 T. Helgaker, M. Jaszuński and K. Ruud, Chem. Rev., 1999, 99, 293-352.

34 Y. Arima, Y. Nakai, R. Hayakawa and T. Nishino, J. Antimicrob. Chemother., 2003, 51, 113-122.

35 Y.-H. Shih, D.-J. Lin, K.-W. Chang, S.-M. Hsia, S.-Y. Ko, S.-Y. Lee, S.-S. Hsue, T.-H. Wang, Y.-L. Chen and T.-M. Shieh, PLoS One, 2014, 9, e94941.

36 C. A. Lipinski, F. Lombardo, B. W. Dominy and P. J. Feeney, Adv. Drug Delivery Rev., 2001, 46, 3-26.

37 W. L. Jorgensen and E. M. Duffy, Adv. Drug Delivery Rev., 2002, 54, 355-366.

38 H. Guo, D. Jiang, T. Zhou, A. Cuconati, T. M. Block and J.-T. Guo, J. Virol., 2007, 81, 12472-12484.

39 G. Repetto, A. del Peso and J. L. Zurita, Nat. Protoc., 2008, 3, 1125.

40 G. M. Sheldrick, Acta Crystallogr., Sect. A: Found. Crystallogr., 2008, 64, 112-122. 